\title{
Information system for the management of intelligent traffic lights
}

\section{Sistema de información para la gestión de la infraestructura de semáforos inteligentes de tránsito}

\author{
ORTIZ-FIGUEROA, Alejandro $\dagger^{*}$, CHÁVEZ-VALDEZ, Ramona Evelia, VERDUZCO-RAMIREZ, \\ Jesús Alberto and VILLAVICENCIO-JACOBO, Ismael
}

Instituto Tecnológico de Colima, México

ID $1^{\text {st }}$ Author: Alejandro, Ortiz-Figueroa / ORC ID: 0000-0001-6745-0805, CVU CONACYT ID: 933945

ID $1^{\text {st }}$ Coauthor: Ramona Evelia, Chavez-Valdez, ORC ID: 0000-0002-5697-6825, CVU CONACYT ID:435574

ID $2^{\text {nd }}$ Coauthor: Jesús Alberto, Verduzco-Ramirez / ORC ID: 0000-0001-5041-3741, CVU CONACYT ID: 256074

ID $3^{\text {rd }}$ Coauthor: Ismael, Villavicencio-Jacobo / ORC ID: 0000-0002-0990-2372, CVU CONACYT ID: 934174

DOI: $10.35429 / J R D .2020 .17 .6 .21 .26$

Received: January 12, 2020; Accepted: June 30, 2020

\begin{abstract}
Derived from the population increase and urban growth, vehicle traffic has increased in the cities of Colima and Villa de Álvarez located in Mexico, and with it the problems of road safety and traffic management; the increasing number of roads and traffic lights implies recording the information of each one of these; Therefore, this article presents an information system for the management of intelligent traffic light infrastructure. In the software engineering process, the Agile Unified Process was used to manage the main risks early and guarantee the quality of the product during its life cycle. The system was tested at a prototype level with satisfactory results, as a result a web system contributes to improving road and citizen safety, since based on two vehicle data it connects with web services to other databases, and identifies Immediately form the incidents of vehicles that pass through the roads, including stolen vehicle, speeding and a panic button. The expectations are to scale it to the real environment, and make available to the corresponding authorities the information collected to favor decision-making.
\end{abstract}

Road infrastructure, Urban mobility, Vehicular traffic

\begin{abstract}
Resumen
Derivado del aumento poblacional y el crecimiento urbano, el tráfico vehícular se ha incrementado en la zona conurbada Colima-Villa de Álvarez, México, y con ello los problemas de seguridad vial y la gestión del tráfico; el creciente número de vías y de semáforos, implica registrar la información de cada uno de éstos; por ello, en este trabajo se presenta un sistema de información para la gestión de la infraestructura de semáforos inteligentes de tránsito. En el proceso de ingeniería de software se utilizó el Proceso Unificado Ágil, para gestionar de forma temprana los principales riesgos y garantizar la calidad del producto durante su ciclo de vida. El sistema fue probado a nivel prototipo con resultados satisfactorios, como resultado se tiene el sistema web que contribuye a mejorar la seguridad vial y ciudadana, pues basado en dos datos de los vehículos se conecta con servicios web a otras bases de datos, e identifica de forma inmediata las incidencias de los vehículos que transitan por las vialidades, entre ellas vehículo robado, exceso de velocidad, botón de pánico. Las expectativas son escalarlo al ambiente real, y poner a disposición de las autoridades correspondientes la información recabada para favorecer la toma de decisiones.
\end{abstract}

Infraestructura vial, Movilidad Urbana, Tráfico vehicular

Citation: ORTIZ-FIGUEROA, Alejandro, CHÁVEZ-VALDEZ, Ramona Evelia, VERDUZCO-RAMIREZ, Jesús Alberto and VILLAVICENCIO-JACOBO, Ismael. Information system for the management of intelligent traffic lights. Journal of Research and Development. 2020. 6-17: 21-26.

\footnotetext{
* Correspondence to the Author (Email: ortizfig.a@gmail.com)

$\dagger$ Researcher contributing as first author.
} 


\section{Introduction}

Currently the use of traffic lights continues to be the main tool for controlling vehicular traffic in cities, in some cases, it has been combined with video surveillance systems to recognize the identity of the vehicles that circulate on the roads as a factor to improve the road and citizen safety. The increase in traffic congestion is a challenge for society in general and with it the consequences that this represents. According to [1] these factors increase the stress of travelers as it leads to loss of time and problems related to health.

In the case of Mexico, information presented by [2] from the 2010-2015 intercensal population surveys and by [3] registered vehicle units 2010-2018 obtained their respective increases of $51.06 \%$ and $6.76 \%$, which represents more than six Sometimes the increase in the number of vehicles over the population in just eight years, in such a situation, the government and society make joint efforts to incorporate technological strategies that contribute to improving vehicular traffic.

As with the population and the acquisition of vehicles, road traffic accidents have also increased, according to figures from [4] in the state of Colima, in the last 20 years, these went from 1,604 to 5,310, which represents an increase $231 \%$. These data justify the elaboration of strategies that improve urban mobility, among them the placement of intelligent traffic lights that according to [5] is defined as an intelligent device, to any physical object associated with computer resources and capable of communicating with other similar objects through any transmission method, logical protocol or with humans through a user interface and a communication standard.

The incorporation of Information and Communication Technologies (ICTs) in the area of mobility, have allowed the creation of solutions that have addressed similar problems.

An information system was developed, which according to [6] detects, sends and receives alerts of incidents that any traffic light presents, with the main objective of determining the influence that an information system has on alerting the operation of traffic lights.
In the city of Huarmey, motorcycle taxis are the main means of transportation, [7] implemented a computer system that aims to automate and verify actions such as operating permits, infractions, pending debts, among others, to have better control over them.

In the case of [8], they proposed to establish a vehicle traffic management system in real time, basing its functionality on radio frequency identification (RFID). The system was applied in the city of Delhi, with the aim of having a control of each registered vehicle. On the other hand [9] implemented a system that works through video surveillance, the cheapest technique for monitoring, which allows analyzing both day and night conditions to control traffic and is characterized by providing indicators such as vehicle classification, vehicle density, vehicle count, license plate detection and incident detection. For their part [10] they designed a system that can monitor and control the traffic network remotely, based on the use of Embedded Web Servers, incorporating Linux as the operating system. Another contribution is that of [11] who developed an intelligent traffic system to control road congestion and reduce accidents, based on embedded web technology, using different sensors and communication protocols to connect with the hardware and software used. In turn [12], they carried out a real-time traffic monitoring system, based on the detection and tracking of objects, in order to measure parameters such as speed and vehicle density.

This research work proposes the implementation of an Information System for the Management of the Intelligent Traffic Light Infrastructure (SIGISIT), as a solution to the problem of vehicular mobility; allowing to manage, speed up and consult the information captured through the cameras associated with smart traffic lights, to promote citizen security. The SIGISIT is aimed at the State Public Security Systems as a computer tool for decision-making, and the creation of strategies that favor citizen mobility and security; In its preparation, the requirements of the metropolitan area Colima-Villa de Álvarez, Mexico were considered, although it can be adapted to the needs of any environment. 
In its development the Agile Unified Process was used to control the software engineering process, and in its implementation technologies such as RFID, ANPR camera, Java Spring, PostgreSQL, Jquery and Boostrap. The results obtained from the pilot test indicated that the system as a registration base can support decision-making regarding public safety in the metropolitan area, by virtue of identifying the vehicle data that circulates in real time and sending alerts according to the incidents found.

\section{Methodology}

For the development of this applied research, the Agile Unified Process (PUA) was used, which allowed controlling the software engineering process through iterations and increments; The final product was identified and divided into executable prototypes that gave the development team and the client a clear vision of the project. Figure 1 illustrates the PUA methodology, which [13] considers "serial for the large and iterative for the small"; It is described in four phases and seven disciplines, each phase can have one or more iterations depending on the characteristics of the project and the disciplines considered are executed in each iteration.

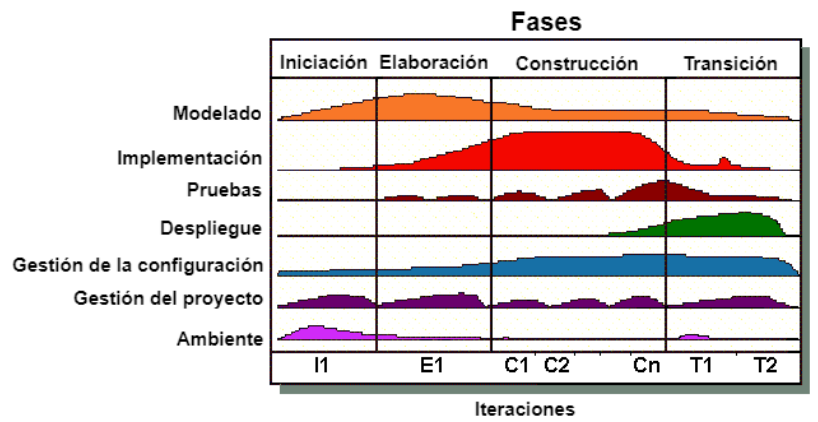

Figure 1. Agile Unified Process Methodology Source:http://www.ambysoft.com/unifiedprocess/agileUP .html, 2005

As it was a small project, five iterations of four weeks each were defined; use cases were prioritized, so in each iteration the activities of:

Modeling: UML diagrams were developed, including use cases, requirements, classes, data and interfaces, using the trial of the Enterprise Architect Project tool.
Implementation: UML models were translated into code using Java programming with Spring framework, PostgreSQL for data management and Bootstrap in front-end development.

Testing: unit tests were applied to the system code, to ensure compliance with functional requirements, as well as integration tests of the various components.

Deployment: incremental deliveries were made and uploaded to the server; for reasons of computational infrastructure and scaling of functionalities, it continues in the pre-production phase.

Configuration management: The system has an administration panel that allows users and permissions to be configured. There is only one version in which changes continue to be incorporated to improve scope and performance.

Project management: The activities program was prepared, considering the tasks to be carried out, those responsible and the execution time; Deliverables and release dates were specified. Conditions were created for deliveries to be executed on time.

Environmental administration: the methodology was followed, favoring change management and risk management; In addition, the team had the necessary software, licenses and devices for the development of the system.

Working with the PUA methodology left the experience of identifying the roles in the development team and the activities that they involve; the iterations marked a slender and transparent job in the assignment and development of tasks; communication with the team and the client allowed the changes to be incorporated and the results to satisfy the client's requirements.

\section{Results}

As a result of this research, SIGISIT was implemented, which records the identification data of each traffic light, with them the traffic light network of the metropolitan area is monitored and visualized through a graphical interface based on maps. 
With the support of a specialized ANPR camera, the system reads the license plate of the vehicle in circulation, the data obtained is compared with official information provided through a web service, in order to detect possible incidents in the vehicle that is circulating. Figure 2 shows the conceptual model of the system, as a contribution to the management of the infrastructure of intelligent traffic lights. It is a web information system that, through the prior registration of traffic lights, centralizes the acquisition of the data generated by the monitoring of vehicle flow to identify parameters such as density and incidents related to road and citizen safety. The cameras are associated with the corresponding traffic light through an IP address so that the system has remote access to each one. The cameras capture and send vehicle information to the information system via the Internet, for registration and consultation.

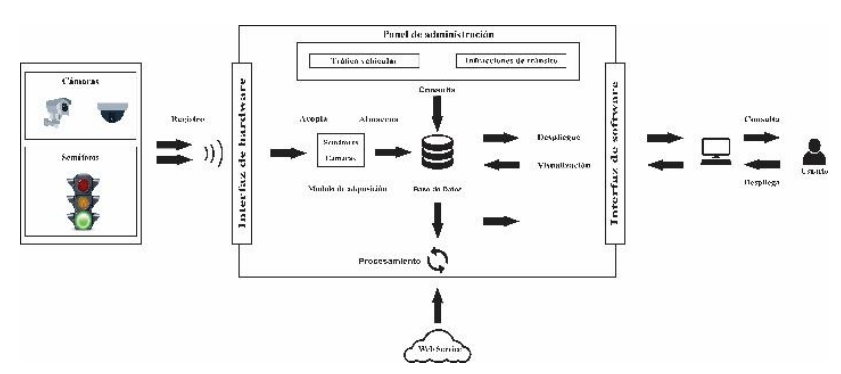

Figure 2 SIGISIT Conceptual Model

Source: self made

The system registers the information received from the cameras in the database and at the same time compares it with the information from the web service. If a match is found regarding the traffic incidents of the vehicle it identified, the corresponding alert is displayed on the administration panel.

Users of the system can consult the information of the traffic light network through the administration panel, which displays the incidents in real time and allows them to consult the detail of each traffic light. Figure 3 shows the main SIGISIT menu, in the scope presented here are the options of Cameras, Traffic Lights and Traffic Light Monitoring.
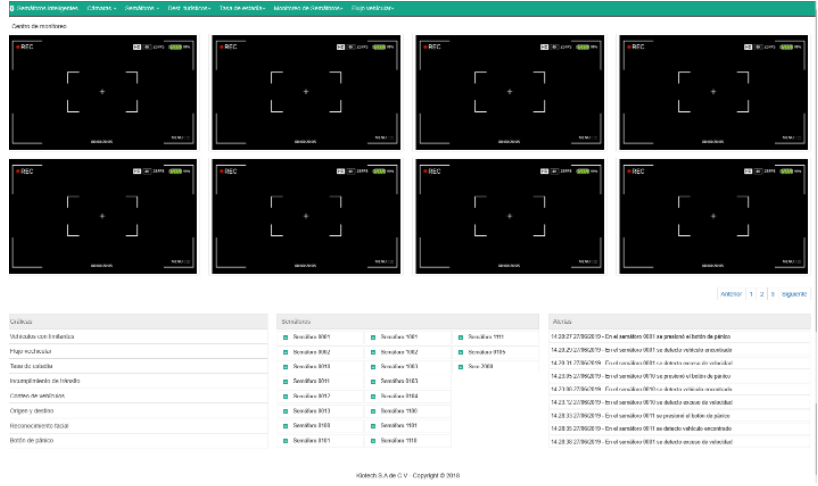

Figure 3 SIGISIT main menu

Source: self made

The system allows observing the incidents or alerts of a particular traffic light, as shown in Figure 4; The physical location of the traffic light is displayed, specifying the streets, coordinates, orientation, locality, state and country, and the details of the latest alerts associated with it are presented.

For traffic light monitoring, the data of each one was previously recorded, the respective cameras were associated and their location was marked using georeferencing. Figure 4 presents a list of the active traffic lights and the history of the traffic lights where there were incidents.

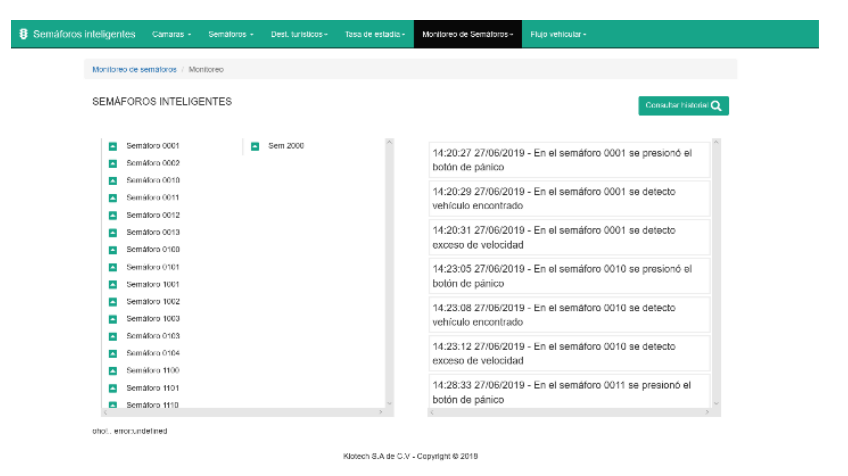

Figure 4 Traffic light monitoring Source: self made

The system allows observing the incidents or alerts of a particular traffic light, as shown in Figure 5; the physical location of the traffic light is displayed, specifying the streets, coordinates, orientation, locality, state and country, and the detail of the latest alerts associated with it is presented. 


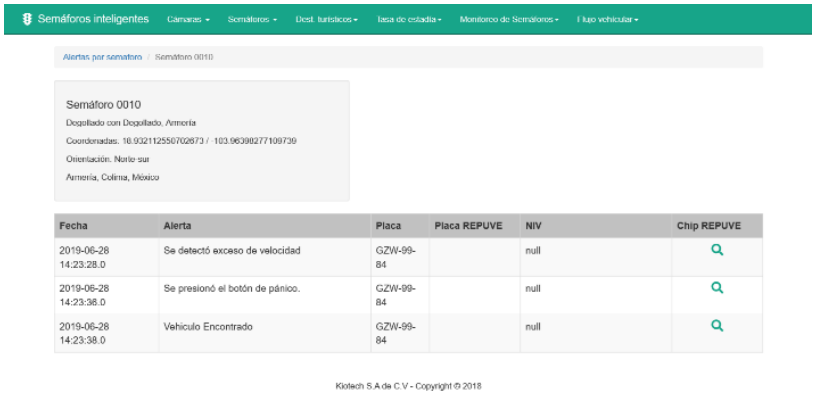

Figure 5 Traffic light history

Source: self made

From the traffic light monitoring view, the cameras associated with each traffic light can be accessed as shown in Figure 6. The model of this system considers video surveillance cameras, traffic light, traffic light cameras for the purpose of reading plates and intercom; for reasons of confidentiality, in the scope of this investigation only the functionalities of the traffic light camera are presented.

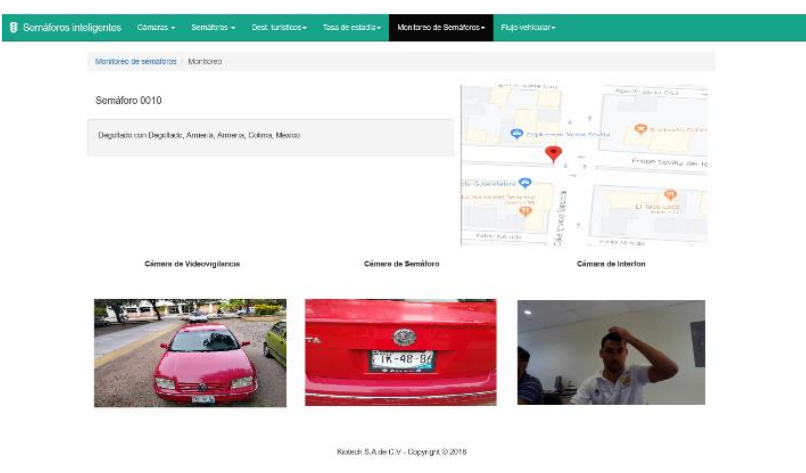

Figure 6 Cameras associated with the traffic light Source: self made

As a result of the systematization of the monitoring, various alerts and notifications were implemented, so that the user of the system can link to the body in charge of the corresponding care, be they medical services or road safety services.

\section{Tests}

SIGISIT was subjected to a series of pilot tests in a controlled environment, based on a sample of 100 traffic lights operating simultaneously and verifying the expected indicators in relation to the programmed readings at the traffic lights as vehicles pass by.

\begin{tabular}{|c|c|c|c|}
\hline Name & Model & Characteristics & Qty. \\
\hline $\begin{array}{l}\text { Traffic } \\
\text { light }\end{array}$ & $\begin{array}{l}\text { Three } \\
\text { horizontal } \\
\text { lights }\end{array}$ & $\begin{array}{l}\text { Three lights } \\
\text { traffic light. }\end{array}$ & 100 \\
\hline \multirow[t]{2}{*}{$\begin{array}{l}\text { ANPR } \\
\text { camera }\end{array}$} & \multirow{2}{*}{$\begin{array}{l}\text { Freeway- } \\
\text { cam } \\
\text { Impinj } \\
\text { Speedway } \\
\text { Revolution } \\
\text { r220 }\end{array}$} & $\begin{array}{l}\text { Capture vehicle } \\
\text { license plates up } \\
\text { to } 255 \mathrm{~km} \text {. }\end{array}$ & \multirow[t]{2}{*}{1} \\
\hline & & $\begin{array}{l}\text { Vandal-proof } \\
\text { IK10 and IP67 } \\
\text { housing. }\end{array}$ & \\
\hline \multirow[t]{2}{*}{$\begin{array}{l}\text { RFID } \\
\text { reader }\end{array}$} & \multirow[t]{2}{*}{$\begin{array}{l}\text { SH-L7423 } \\
\text { JPG }\end{array}$} & $\begin{array}{l}\text { Support for two } \\
\text { antennas. }\end{array}$ & \multirow[t]{2}{*}{1} \\
\hline & & $\begin{array}{l}\text { Read } 200 \text { labels } \\
\text { per second. }\end{array}$ & \\
\hline \multirow[t]{4}{*}{$\begin{array}{l}\text { RFID } \\
\text { tag }\end{array}$} & \multirow{4}{*}{$\begin{array}{l}\text { SQL } \\
\text { Three } \\
\text { horizontal } \\
\text { lights } \\
\text { Freeway- } \\
\text { cam } \\
\text { Impinj } \\
\text { Speedway } \\
\text { Revolution } \\
\text { r220 }\end{array}$} & $\begin{array}{l}\text { Passive } \\
\text { UHF. }\end{array}$ & \multirow[t]{4}{*}{500} \\
\hline & & $\begin{array}{l}\text { Frequency } 860 \sim \\
960 \mathrm{MHz} .\end{array}$ & \\
\hline & & 512 bit memory. & \\
\hline & & $\begin{array}{l}\text { Reading up to } \\
8 \mathrm{mt} \text {. }\end{array}$ & \\
\hline $\begin{array}{l}\text { Vehicle } \\
\text { plates }\end{array}$ & SH-L7423 & & 500 \\
\hline $\begin{array}{l}\text { Web } \\
\text { service }\end{array}$ & JPG & $\begin{array}{l}\text { Plates with } \\
\text { nomenclature of } \\
\text { the Mexican } \\
\text { Republic }\end{array}$ & 1 \\
\hline
\end{tabular}

Table 1 Tools and equipment used Source: self made

Table 1 shows the tools and equipment used for the development of this project.

Regarding the identification of vehicles by means of the vehicle plates and the readings of the labels, a result of 100 percent was obtained, however, the tests in real environment are pending.

\section{Conclusions}

In conclusion, SIGISIT manages to significantly improve the management of the traffic light network, highlighting the following contributions:

Specific and georeferenced identification of each traffic light; Identification and operation of the cameras associated with each traffic light; Traffic light alert history; Identification of incidents by reading plates and crossing information; Improvement in the communication flow of the organisms that intervene in the regulation of vehicular traffic and citizen security; Identification of trends by types of incidents; Elaboration of justified public policies in the information obtained. 
Thus, the implementation of a web system for the management of the network of intelligent traffic lights favors government decision-making to develop public policies that contribute to road safety and citizen safety itself. In the future it is suggested that SIGISIT can be improved and expanded, enabling the system so that alerts or notifications are electronically channeled to the agencies that serve them; In addition, given the information it will store, algorithms can be implemented to identify possible trends in the types of accidents in certain roads or geographical areas..

\section{References}

[1] O. Okorodudu, F., O. Okorodudu, P., \& O. Atumah, L. (2018). A Novel Approach to Road Traffic Monitoring and Control System. International Journal of Multidisciplinary Sciences and Engineering, 29-33. Obtenido de: https://www.researchgate.net/publication/32353 5257_A_Novel_Approach_to_Road_Traffic_M onitoring_and_Control_System

[2] Instituto Nacional de Estadística y Geografía (INEGI). (2018). Parque vehicular (Consultado: 2020/04/05). Recuperado de https://www.inegi.org.mx/temas/vehiculos/defa ult.html\#Informacion_general.

[3] Instituto Nacional de Estadística y Geografía (INEGI). (2015). Encuesta Intercensal (Consultado: 2020/04/05). Recuperado de https://www.inegi.org.mx/programas/intercensa 1/2015/default.html\#Tabulados

[4] Instituto Nacional de Estadística y Geografía (INEGI). (2017). Accidentes de tránsito terrestre en zonas urbanas y suburbanas. (Consultado: 2019/01/18). Recuperado de: https://www.inegi.org.mx/sistemas/olap/proyect os/bd/continuas/transporte/accidentes.asp

[5] Carabelea, C., Boissier, O., \& Rampararany, F. (2003). Benefits and Requiments of Using Muli-agent Systems on Smart Devices. En H. Kosch, L. Boszorményi, \& H. Hellwagner, Euro-Par 2003 Parallel Processing (págs. 10911098). Berlín: Springer-Verlag.

[6] L. Carbajal Saboya, "Sistema de información y su influencia en la alerta de la operatividad de semáforos en la ciudad de Tarapoto", Licenciatura, Universidad Nacional de San Martín, 2019.
[7] J. Gamarra Marquez, "Propuesta de Implementación de un Sistema Informático para el Control de Vehículos Menores en la Municipalidad Provincial de Huarmey", Licenciatura, Universidad Católica los Sngeles Chimbote, 2019.

[8] Saini, A., Chandok, S., \& Deshwal, P. (2017). Advancement of Traffic Management System Using RFID. IEEE, 1254-1260. Recuperado de: https://ieeexplore.ieee.org/document/8250669

[9] Nemade, B. (2016). Automatic Traffic Surveillance Using Video Tracking. Procedia Computer Science, 402-409. Recuperado de: https://www.sciencedirect.com/science/article/p ii/S1877050916001836

[10] R. Dube Rajendra., \& S. Pawar Shushama. (2015). Design and Implementation of Traffic Monitoring System Base on Embebed Web Technology. Revista International Journal of Sciencie and Research (ISJR),6.14, 1943-1946. Obtenido de: https://pdfs.semanticscholar.org/83b0/4464201f 44f915164452e0edca2f56aa75aa.pdf

[11] Shrikhande N. Madhavi., Shende K. Dipali (2014). Embeded Web Technology in Traffic Monitoring Syten. Revista International Journal of Innovative Research in Advanced Engineering (IJIRAE),1(4), 114-117. Recuperado de: http://ijirae.com/images/downloads/vollissue4/ MYEC10084-21.pdf

[12] Kiratiratanapruk, K. \& Siddhichai, S. (2009). Practical Application for Vision-based Traffic Monitoring System. IEEE. Recuperado de:

https://ieeexplore.ieee.org/document/5137245

[13] Ambler, S. (2014). The Agile Unified Process (AUP). Recuperado de: www.ambysoft.com/unifiedprocess/agileUP.ht $\mathrm{ml}$. 